\title{
Manganese Concentrations In Hair and Fingernail of Some Kano Inhabitants
}

\author{
AYODELE, J.T.; BAYERO, A.S \\ Department of Chemistry, Bayero University, P.M.B 3011, Kano-Nigeria.E mail: tjayodele@yahoo.com
}

\begin{abstract}
Manganese concentrations in hair and fingernails were determined by Flame Atomic Absorption Spectrometry (AAS).The mean manganese in hair and fingernail were $0.54 \pm 0.35 \mathrm{mg} / \mathrm{g}$ and $0.68 \pm 0.30 \mathrm{mg} / \mathrm{g}$ respectively. A progressive decrease in manganese concentrations in hair and fingernails with age indicated no significant difference in their means suggesting that manganese in hair and fingernails originate from a common source. Comparing the mean manganese concentrations in hair with the fingernails a significant difference is indicated in the two tissues $(\mathrm{p} \leq 0.05)$. Human hair and fingernails are therefore recording filaments that can reflect metabolic changes of many elements over long periods of time and hence furnish an imprint of post nutritional event as dietary levels of essential micro-elements. @ JASEM
\end{abstract}

Manganese is an essential trace element in human nutrition (Keen et al.,1999). Its richest dietary sources include whole grains, nuts, leafy vegetables and teas(Pennington and Young,1991; FreelandGraves,1994;Gibson,1994). Manganese is concentrated in the bran of grains removed during processing. The mean intake of manganese world wide range from 0.52 to 10.8 milligrams daily. Concomitant intake of manganese with foods rich in phytic acid or oxalic acid may depress its absorption (Keen et al.,1989; Keen and ZidenbergCherr,1996).

In the body, manganese facilitates enzyme functions and many cell processes (Aras and Ataman, 2006). Elevated levels may reflect occupational exposure (Chatt and Katz, 1988). Increased manganese concentrations were found in hair samples of school children scoring poorly in tests to assess general intelligence, visual motor skills, receptive language, verbal memory, nonverbal problem solving and behavioral problems (Wright, et al., 2006). In archaeological bone, manganese is often correlated with aluminium (Pate and Hutton, 1988).

Hair manganese levels correlate with its levels in other body tissues such as urine, saliva, sweat and human milk (Barret,1985; Hull,2003;Afridi et al.,2006a\&b; Kazi et al.,2008).Manganese is the preferred metal co-factor for glycosyltransferases important in the synthesis of glycoproteins and glycosaminoglycans (mucopolysaccharides). It is a component of the metalloenzyme manganese superoxide dismutase (MnSOD) in the mitochondria and is a constituent of the mitochondrial oxidant defense system (Nielsen, 1999).

Symptoms associated with manganese deficiency include fatigue, lack of physical endurance, slow growth of fingernails and hair, impaired metabolism of bone and cartilage, dermatitis, weight loss, reduced fertility, increased allergic sensitivities and inflammation (Baly et al., 1990; Davis et al., 1990). Deficiency signs include nausea, vomiting, change in hair colour and neurologic sequela (Fred, 1998). Manganese is toxic under certain conditions. Patients with endstage liver disease accumulate manganese in their basal ganglia. Manganese plays a role in the hepatic encephalopathy in those with liver failure and is eliminated through the bile, and hepatic dysfunction leads to depressed manganese excretion (Krieger et al., 1995). Mine workers exposed to high concentrations of manganese dust develop "locuramanganica" or manganese madness. In later stages of this disease, symptoms similar to Parkinson's disease are observed (Nagatomo et al., 1999).The aim of the present study was to determine the concentration of manganese in scalp hair and fingernails from some inhabitants resident in Kano.

\section{MATERIALS AND METHODS}

Sampling: The hair samples were collected according to the recommendation of IAEA (1991). Human hair were taken from the scalp part. Precleaned stainless steel scissors and trimmers were used for collection of specimens and clean bags were used for sample storage. The hair samples were washed with acetone and deionized water and air dried according to the procedure recommended by IAEA for human hair (IAEA.1991)

Manganese was determined from various subjects resident in Kano for at least six months. Hair $(n=350)$ and fingernail $(n=300)$ samples were collected from subjects in the age range of 155 years.

Nail samples were collected in polyethylene containers and were washed in $1 \%$ solution of TRITONX-100 in de-ionized water in an ultra sonic bath and on drying were stored in small plastic tubes (Iyengar,1984). Hair samples were collected from each subject as close to the scalp as possible (Kucera et al.,1996).Cleaning of hair and nail samples prior to determining the manganese content was done using distilled water, organic solvents and a mixture of organic solvent and a nonionic detergent. The hair samples were washed using three different washing methods. Distilled water was initially employed (Chittleborough, 1980 ) followed by a $50 \%$ solution of ethanol and 
acetone (Kucera et al.,1996) and finally a $1 \%$ solution of nonionic detergent (Extran MA01 or Teepol),distilled water and acetone (Schrauzer et al.,1988; Nowak,1998; Martin et al., 2005) after which they were kept in an alcohol -ether mixture for $45 \mathrm{mins}$ and dried at $60^{\circ} \mathrm{C}$ for $72 \mathrm{hr}$.

$0.5 \mathrm{~g}$ of each sample was digested in $10 \mathrm{~cm}^{3}$ concentrated $\mathrm{HNO}_{3}$ and the resulting solution was evaporated to dryness and redissolved in $0.1 \mathrm{M}$ nitric acid (Nnorom et al., 2005). Manganese concentrations were determined by Flame Atomic Absorption on a Model 210 VGP Spectrophotometer attached to IBM computer. The result of the absorbance of each sample was the average of ten sequential readings. Background light absorption and scattering were compensated for either by deuterium hollow cathode lamp. Distilled water was digested as blank using the same procedure previously described (Ayodele and Abubakar, 1998; Ayodele and Abubakar, 2001)

Statistical Analysis: All statistical computations were on the PC 486 66MHZ microcomputer using the integrated statistical package for windows from Umstat Ltd.(London) or dedicated micro instructions for the Excel spread sheets from Microsoft. The approach enabled the advantages of the various computational and graphical facilities of both types of software's to be used with the

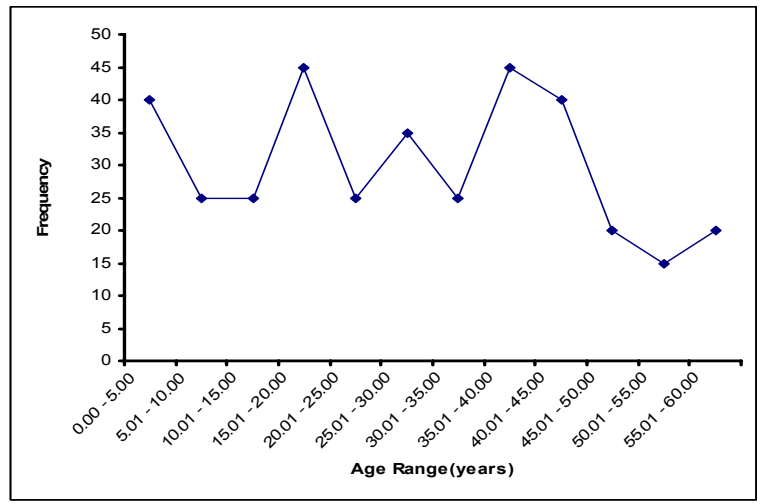

Fig 1: Frequency Distribution Pattern for Age (years) of Donors in Hair

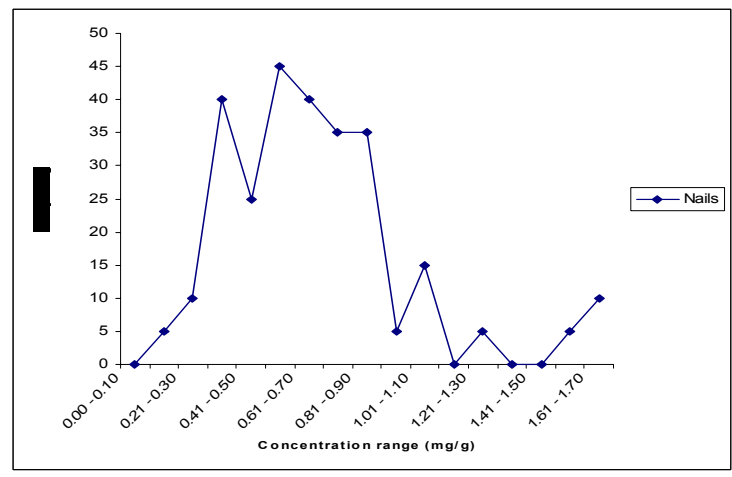

Fig. 3: Frequency Distribution Pattern for Manganese in Fingernails ability to read different file formats. The analyses of variance (ANOVA) were carried out according to described procedures (O’Mahony, 1986).

\section{RESULTS AND DISCUSSION}

The frequency distribution pattern for the age of hair and fingernail donors is as shown in Fig.1.The distribution is multimodal with a mean age of 27.51 \pm 16.5 years. The frequency distribution pattern for manganese in hair is as shown in Fig.2. The distribution is multimodal and is skewed towards high frequency of low concentration with a mean and standard deviation of $0.54 \pm 0.35 \mathrm{mg} / \mathrm{g}$ while the frequency distribution pattern for manganese in fingernails (Fig. 3) is multimodal and is skewed towards high frequency of low concentration with a mean and standard deviation of $0.68 \pm 0.30 \mathrm{mg} / \mathrm{g}$. Pearson parametric correlation showed a significant correlation between the manganese content in hair and fingernails $(p<0.05)$ Table 1 . The analysis of variance (ANOVA) revealed that the mean manganese concentration of manganese in hair is not significantly different from that in the fingernails at $p>0.05$ (Table 2). The levels obtained in this study are in agreement with mean manganese in hair and fingernails reported by other authors worldwide (Table3).

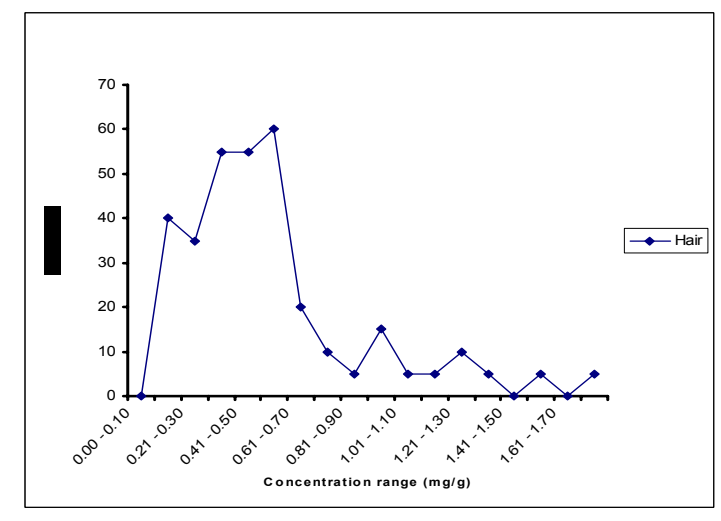

Fig. 2: Frequency Distribution Pattern for Manganese

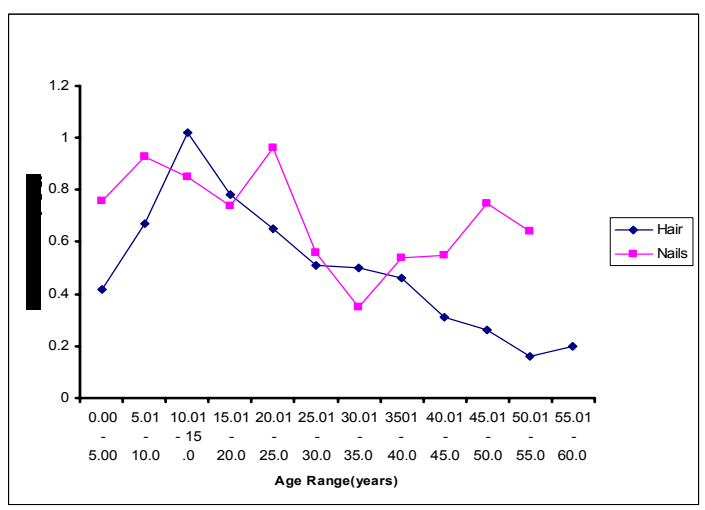

Fig. 4.: Manganese Concentration ( $\mathrm{mg} / \mathrm{g})$ in hair and Fingernails with respect to age

* Corresponding author: Ayodele, J.T. 
Table 1: Parametric Correlation Coefficients for Manganese in Hair and Fingernails

\begin{tabular}{ccc}
\hline & Hair & Fingernails \\
\hline Hair Pearson correlation & 1 & .91 \\
Sig. (2-tailed) &. & .501 \\
$\mathrm{~N}$ & 350 & 300 \\
\hline Fingernails Pearson Correlation & .091 & 1 \\
Sig. (2-tailed) & .507 &. \\
$\mathrm{~N}$ & 300 & 300 \\
\hline
\end{tabular}

Table 2:Analysis of variance for Manganese in Hair and Fingernails

\begin{tabular}{ccccccc}
\hline Source of variation & SS & Df & MS & F & P-valve & F crit \\
\hline Between Groups & 0.574568 & 1 & 0.57456818 & 6.38530834 & 0.0136633 & 3.9290115 \\
Within Group & 9.872764 & 108 & 0.09141448 & & & \\
\hline Total & 10.44733 & & & & \\
\hline
\end{tabular}

Table3: :Results of manganeseConcentrations in Hair and Nails from different Countries

\begin{tabular}{|c|c|c|c|}
\hline Country & Mean & Unit & References \\
\hline & $0.5-1.5$ & $\mu \mathrm{g} / \mathrm{g}$ & Iyengar and Iyengarl(1994) \\
\hline Poland & $0.601 \pm 0.59$ & $\mathrm{mg} / \mathrm{kg}$ & Chojnacka et al(2005) \\
\hline India & $8.81-43.19$ & $\mu \mathrm{g} / \mathrm{g}$ & Mehra and Juneja (2005) \\
\hline Poland & 70.9-951.6 & $\mu \mathrm{g} / \mathrm{kg}$ & Grybos et al(2005) \\
\hline Brazil & $0.105-2.5$ & $\mu \mathrm{g} / \mathrm{g}$ & Saiki et al (1998) \\
\hline Czech & $0.62-1.97$ (hair) & $\mathrm{mg} / \mathrm{kg}$ & Katz and Chatt (1988) \\
\hline Peru & $1.01-6.40$ & $\mathrm{mg} / \mathrm{kg}$ & Bergfield (2007) \\
\hline Czech & $0.729-1.757$ (nail) & $\mathrm{mg} / \mathrm{kg}$ & Kucera et al (2001) \\
\hline Poland & $0.26-0.75$ (hair) & $\mathrm{mg} / \mathrm{kg}$ & Mickeley et al(1998) \\
\hline Poland & 2.41 & “" & Nowak (1998) \\
\hline Sweden & 0.560 & “" & Rodushkin \&Axelssom (2000) \\
\hline & $1200(200-4000)$ & $\mu \mathrm{g} / \mathrm{kg}$ & Iyengar andWoittiez(1988) \\
\hline Brazil & 5 & $\mathrm{mg} / \mathrm{kg}$ & Mickeley et al(1998) \\
\hline Nigeria & $0.62-4.74$ & $\mu \mathrm{g} / \mathrm{g}$ & Oluwole et al (1994) \\
\hline Nigeria & $0.54 \pm 0.35$ (hair) & $\mathrm{mg} / \mathrm{g}$ & This study \\
\hline Nigeria & $0.68 \pm 0.30$ (nail) & $\mathrm{mg} / \mathrm{g}$ & This study \\
\hline
\end{tabular}

Manganese concentration in hair and fingernails with respect to age is as shown in Fig.3 Manganese levels in both hair and fingernails decreased with age, but the decrease is pronounced in hair, indicating that manganese may be playing some physiological functions (Hull, 2003).

Scalp hair and fingernails can record the level and changes of elements in the body over a long period of time(.Saiki et al.,1998; Khuder et al.,2008) Changes in the elemental composition of hair therefore depend on alterations of external and internal media of the human body, and it is considered that hair and fingernails of healthy individuals contain each element within a well defined range of concentration and may be considered as a potential indicator of both external and internal long term exposure to pollutants. The idea of hair and fingernail analysis is inviting, since it is painlessly removed, normally discarded, easily stored and transported to the laboratory for analysis. Analysis is simple and painless, mineral concentrations are not subjected to rapid fluctuations due to diet or other variables and therefore reflect a long - term nutritional status. Samples are stable at room temperature, analytical methods are easy because mineral concentrations in hair are relatively high (Borel and Anderson, 1984;
Ayodele and Bayero, 2008; Ayodele and Bayero, 2009).

\section{REFERENCES}

Afridi,H.I.,Kazi,T.G.,Jamali,M.K.,Kazi,G.H.,Arain M.B.,Jalbani,N.andMemon,A.R(2006a).Atomi $\mathrm{c}$ absorption spectrometric determination of $\mathrm{Zn}$ and $\mathrm{Cr}$ levels in scalp human hair samples. Influence of age gender and diabetic condition. J.Indian Chemical Soc.83(10):1062-1064.

Afridi, H.I., Kazi, T.G., Jamali, M.K., Kazi, G.H.and Shar, G.Q (2006b. The Status of trace and toxic elements in biological samples (scalp hair) of skin-disease patients and normal subjects. Turkish J. Med Sci. 36(4):223-230.

Aras NK and Ataman OY. 2006. Trace Element Analysis of Food and Diet. Cambridge: The Royalty Society of Chemistry Publishing.

Ayodele, J. T. and Abubakar, M. B. (1998). Trace element contamination of rain water in the semi arid region of Kano. Environ. Manag. and Heath 9:176 - 81.

Ayodele, J. T. and Abubakar, M. B. (2001). Cleopatra bulimoides and mutellarubens as 
bioindicators of trace metals in Tiga Dam, Kano, and Nigeria. Research J. of Sci.7:45 - 9.

Ayodele, J.T and Bayero, A.S (2008). Nickel and iron in hair and nail of some Kano inhabitants. Scientia Africana. 7:1-11.

Ayodele, J.T. and Bayero, A.S (2009).Lead and zinc concentrations in hair and nail of some Kano inhabitants .African J. Environ Sci. and Tech.3: $164-170$

Baly, D.L; Schneiderman, J.S; and Garcia-Welsh, A.L (1990).Effect of manganese deficiency on insulin binding, glucose transport and metabolism in rat adipocytes. $J$ Nutri 120:1075-1079

Barrett, S. (1985) .Commercial hair analysis: Science or scam? JAMA 254:1041-1045

Bergfield, R.A (2007). Dietary Analysis of Archaeological Hair Samples From Peru A University of Missouri-Columbia Master of ArtsThesis.p40

Borel ,J.S and Anderson, R.A (1984). Chromium in Biochem of the Essent. ultratrace element (Ed: E. Frieden) Plenum Pub. Co. pp. $332-45$.

Chatt A and Katz SA. 1988. Hair Analysis; Applications in the Biomedical and Environmental Sciences. New York, NY: VCH Publishers.

Chittleborough, G (1980).A chemist view of man hair for trace elements. Sci. Total Environ.: $14: 53-75$

Chojnacka, A and Gorecki, H.G (2005).The effect of age, sex, smoking habit and hair colour on the composition of hair. Environ Toxicol and Pharmacol.22:52-57

Chojnacka, A and Gorecki , H.G (2006b).The influence of living habits and family relationships on element concentrations in human hair. Sci. Total Environ.366:612-620.

Contiera, E and Folin, M (1994).Trace elements nutritional status. Use of hair as a diagnostic tool. Bio Trace Elem Res.40:151-160.

Davis, C.D; Ney, D.M; and Greiger J.L(1990).Manganese, iron and lipid interactions .J Nutri.120:507-513.

Fred, Y.L. (1998).Role of trace metals in nutrition and disease. www.biochem.uwo.ca/ fao/ eung/htm/.

Freeland -Graves, J (1994). Derivation of manganese safe an adequate daily intakes. In :Risk Assessment of Essential Elements

* Corresponding author: Ayodele, J.T.
(Mertz, W., Abernathy, C.O and Olin, S. S eds) ILSI Press ,Washington, DC. PP237-252.

Gibson, R.S (1994).Content and bioavailability of trace elements in vegetarian diets. Amer J. Clin. Nutri.59:1223S-1232S.

Grybos, R; Zagroszki, P; Krosniak, L; Lagan, L; Szklarzewicz, J; Golas, J and Przybylski, W (2005).Level and Relationship of Elements in Scalp Hair of Males: Effect of Air Pollution and Smoking Habits. Polish J. Environmental Studies.14:35-40.

Hull, J. S. (2003). Hair Analysis program. www.hairanalysisprogram.com

IAEA (1991).International Atomic Energy Agency. Report on the Fiest Research Coordination Meeting,NAHRES-7 Vienna

Inyengar, G.V (1984).Preservation and Preparation of Biological Materials for Trace Element Analysis: Quality Assurance Considerations, Quality Assurance in Biomedical Neutron Activation Analysis, IAEA Tecdoc323,International Atomic Energy Agency, Vienna p89.

Iyengar G.V and Iyengar V. 1994. Trace Element in Environmental and Health Sciences. In Alfassi ZB. Editor. Determination of Trace Elements. Weinheim: VCH

Iyengar G.V. and Woittez, J.(1988).Trace element in human clinical specimens: Evaluation of literature data to identify reference values. Clin. Chem.34:474-481.

Katz, S.A and Chatt, A (1988) The significance of hair analysis. In: Hair Analysis: Applications in the Biomedical and Environmental Sciences. New York, NY: VCH Publishers; 1988:105109.).

Kazi TG, Jalbani N, Kazi N, Jamali MK, Arain MB, Afridi HI, Kandhro A, Pirzado Z (2008). Eval. of toxic metals in blood and urine samples of chronic renal failure patients, before and after dialysis. RenalFailure.30(7):737-745.

Keen, C.L and Zidenberg-charr, S.(1996) Manganese . In: Ziegler, EE , Filer, L. J eds Present knowledge of nutrition, $7^{\text {th }}$ ed. .Washington, DC:ILSI Press.334-34

Keen, C.L, Ensunsa, J. L and Watson, M. H (1999). Nutritional aspects of manganese from Experimental studies. Neurotoxicol, 20:213 23. 
Keen, C.L; Tamura, T; Lonnerdal, B; Hurley, L.S and Halstead, C.H (1985).Changes in hepatic superoxide dismutase activity in alcoholic monkeys. Amer .J. Clin. Nutri.41:929-932.

Khuder, A; Bakir, M.A; Hasan, R and Mohammed, A (2008).Determination of nickel, copper ,zinc and lead in human scalp hair in Syrian occupationally exposed workers by total reflection X-ray fluorescence .Envi. Monit. Assess. 143:67-74.

Krieger, D., Krieger, S., and Jansen, O. (1995).Manganese and chromic hepatic enxephalopathy. Lancet 346:270-74.

Kucera, J., Lener, J., Soukal, L. and Horakova, J (1996). Air Pollution and Biological Monitoring of Environmental Exposure to Vanadium Using Short Time Neutron Activation Analysis .J. Trace and Microprobe Techniques 141(1):193

Kucera J, Bencko V, Papayova A, Saligova D, Tejral J, Borska L.(2001). Monitoring of occupational exposure in manufacturing of stainless steel constructions. Part I: Chromium, iron, manganese, molybdenum, nickel and vanadium in the workplace air of stainless steel welders. Cent Eur J Public Health. 9(4):171-5.

Martin, R.R., Kempson, I.M., Naftel., S.J and Skinner, W.M (2005).Preliminary synchrotron analysis of lead in hair from a lead smelter worker Chemosphere 58:1385-1390.

Mehra, R and Juneja, M (2005).Fingernails as biological indices of metal exposure. $J$.Biosci 30:101-105

Mickeley, N; Dias Cameiro, M.T.W and Portoda Silveira, C.L (1998). How reliable are human hair reference intervals for trace elements? $\mathrm{Sci}$ Total Environ.218:9-17

Nagatomo, S., Umehara, F. and Hanada, K. (1999). Manganese intoxication during total parental nutrition J. Neurol Sci., 162:102 - 105

Nielsen, F. H. (1999). Uitratrace minerals. Modern nutrition in Health and Disease, 9th Ed. 283 303.

Nnorom, I.C; Igwe, J.C and Ejimone, J.C (2005).Multielement analyses of human scalp hair samples from three distant towns in Southeastern Nigeria. Afri.J.Biotech.4:11241127

Nowak (1998).Contents and relationship of elements in human hair for a non-industrialized population in Poland Sci.Total.Environ.209:5968.

Oluwole,A.F;Ojo,J.O;Durosimi,M.A;Asubiojo,O.I; Akanle,O.A;Spyrou,N.M. and Filby, R.H (1994).Elemental Composition o Head Hair and Fingernails of some Nigerian Subjects .Biol Trace Element Res.43:443-452

O’Mahony, M (1986) Sensory Evaluation of food. Statistical methods and procedures. Marcel Dekker Inc. New York USA. pp. 50-55.

Pate, D. and Hutton, J.T. ,(1988).The use of soil chemistry data to address post mortem diagenesis in bone mineral. J. Archaeological Sci.15:729-735.

Pennington, J.A.T; and Young ,B.E (1991).Total diet study nutritional elements 19821989.J.Amer.Diet.Assoc.91:179-183.

Rodushkin and Axelssom (2000) .Application of double focusing sector field ICP-MS for multielemental characterization of human hair and nails. Part II: A study of the inhabitants of northern Sweden. Sci Total Environ. 2000; 262:21-36.

Saiki M, Vasconcellos MBA, de Arauz LJ, and Fulfaro R. (1998). Determination of Trace Elements in Human Head Hair by Neutron Activation Analysis. $J$ of Radioanalytical and Nuclear Chemistry 236(1-2):25-28.

Schrauzer, G.N; Shrestha, K.P and Flores-Arc, M.F (1988).Lithium in human scalp hair of adults, students and violent criminals. Effects of supplementation and evidence for interaction of lithium with vitamin $\mathrm{B}_{12}$ and other trace elements. Bio Trace Eleme.Res 34:161-176.

Siedel, S; Kreutzer, R; Smith, D, McNeel, S and Gilliss, D(2001).Assessment of Commercial Laboratories Performing Hair Mineral Analysis. J. Amer Med Assoc.285:67-72

Sturaro, A; Pavoli, G; Doretti, L; Allegri; Costa, C (1994).The influence of colour, age, sex on the content of zinc, copper, nickel, manganese and lead in human hair. Biol. Trace Elem Res.40:18.

Wright, R. O., C. Amarasiriwardena, C; Woolf ,A.D; Jim ,R,; and Bellinger ,D.C (2006). Neuropsychological Correlates of Hair Arsenic, Manganese, and Cadmium Levels in School-Age Children Residing Near a Hazardous Waste Site. Neurotoxicology 27(2): 210-6. 